\title{
THE ELECTROLYTIC PREPARATION OF POTASSIUM FERRICYANIDE
}

BY O. W. BROWN, C. O. HENKE AND I. L. MILLER

The electrolytic oxidation of potassium ferrocyanide to potassium ferricyanide has been investigated by several men, including Hayek, ${ }^{1}$ Brochet and Petit, ${ }^{2}$ and Grube. ${ }^{3}$ The results obtained by these men, as reported in the literature, seem to be somewhat at variance. All of them used a cell with a diaphragm, the oxidation being effected in the anode chamber. In each case the electrolyte in the anode chamber was agitated with a mechanical stirrer.

Brochet and Petit state that the oxidation of potassium ferrocyanide to potassium ferricyanide takes place according to the following reaction:

$$
{ }_{3} \mathrm{~K}_{4} \mathrm{Fe}(\mathrm{CN})_{6}+\mathrm{Fe}(\mathrm{CN})_{6}{ }_{6} \mathrm{IV}={ }_{4} \mathrm{~K}_{3} \mathrm{Fe}(\mathrm{CN})_{6} \text {. }
$$

Near the end, when the solution is poor in ferrocyanide, oxygen is evolved. To account for this reaction, Brochet and Petit give the equation

$$
\mathrm{Fe}(\mathrm{CN})_{6} \mathrm{IV}+{ }_{2} \mathrm{H}_{2} \mathrm{O}=\mathrm{H}_{4} \mathrm{Fe}(\mathrm{CN})_{6}+\mathrm{O}_{2} \text {. }
$$

Hayek claims that a current yield of $100 \%$ can be obtained. He also states that, with too high a current density, the current efficiency is decreased through the decomposition of water by the ferrocyanide ion, whereby free alkali at the anode is neutralized, and through the electrolytic decomposition of potassium hydroxide.

Grube gives the following table to show the effect of current density on current efficiency: (I904).

${ }^{1}$ Hayek: Zeit. anorg. Chem., 39, 240. (I904); Jour. Chem. Soc., 86, 479

2 Brochet and Petit: Comptes rendus, 139, 855 (1904); Zeit. Elektrochemie, II, IO4 (I905).

${ }^{3}$ Grube: Zeit. Elektrochemie, 20, 334 (ì) 4 ). 
TABLE I

Influence of current density on current efficiency.

Anode solution- 0.5 molar $\mathrm{K}_{4} \mathrm{Fe}(\mathrm{CN})_{6.3} \mathrm{H}_{2} \mathrm{O}$ (46.76 grams of the salt in anode chamber at start).

Cathode solution-o.r normal $\dot{\mathrm{K}} \mathrm{OH}$.

Temperature $-18^{\circ} \mathrm{C}$.

Electrodes-Nickel.

\begin{tabular}{c|c|c|c|c}
\hline \hline No. & $\begin{array}{c}\text { Amperes } \\
\text { per sq. dem. }\end{array}$ & $\begin{array}{c}\mathrm{K}_{4} \mathrm{Fe}(\mathrm{CN})_{6.3} \mathrm{H}_{2} \mathrm{O} \\
\text { when } \mathrm{O} \text { appeared } \\
\text { Grams }\end{array}$ & $\begin{array}{c}\text { Percent oxidized } \\
\text { when O ap- } \\
\text { peared }\end{array}$ & $\begin{array}{c}\text { Current effi- } \\
\text { ciency for com- } \\
\text { plete oxidation }\end{array}$ \\
\hline & 2.0 & 7.62 & $83.7 \mathrm{O}$ & 80.57 \\
$\mathrm{I}$ & $\mathrm{I.5}$ & $5.7 \mathrm{O}$ & $87.8 \mathrm{I}$ & 83.06 \\
2 & $\mathrm{I} . \mathrm{O}$ & 3.48 & 92.56 & 90.49 \\
3 & 0.5 & 2.05 & 95.62 & $94.5 \mathrm{I}$ \\
4 & & &
\end{tabular}

Until bubbles of oxygen began to appear, Grube claims a current efficiency of 100\%. The table shows that with a lowering of current density the current efficiency is increased, a fact which one would expect.

The effect of temperature on current efficiency was also investigated by Grube. His results are given in the following table:

TABLE II

Influence of temperature on current efficiency.

Anode-Platinum.

2.0 amperes per sq. dcm.

\begin{tabular}{c|c|c|c|c}
\hline No. & $\begin{array}{c}\text { Temperature } \\
\text { centigrade }\end{array}$ & $\begin{array}{c}\mathrm{K}_{4} \mathrm{Fe}(\mathrm{CN})_{6.3} \mathrm{H}_{2} \mathrm{O} \\
\text { at start } \\
\text { Grams }\end{array}$ & $\begin{array}{c}\text { Percent oxidized } \\
\text { when O ap- } \\
\text { peared }\end{array}$ & $\begin{array}{c}\text { Current } \\
\text { efficiency }\end{array}$ \\
\hline I2 & I8 & $4 \mathrm{I} .97$ & 84.08 & 78.03 \\
I3 & 40 & $4 \mathrm{I} .97$ & $9 \mathrm{I} .14$ & 83.39 \\
I4 & 50 & 42.24 & 92.97 & 86.46 \\
I5 & 60 & 42.24 & 84.54 & 74.68 \\
I6 & 70 & $4 \mathrm{I} . \mathrm{I} 5$ & 77.88 & 70.38
\end{tabular}

Thus the current efficiency according to Grube increases with temperature up to $50^{\circ} \mathrm{C}$ after which it decreases with increase in temperature. He accounts for the decrease above $50^{\circ} \mathrm{C}$ by assuming a chemical decomposition of the potassium ferricyanide according to the following equation: 


$$
\begin{aligned}
& { }_{13} \mathrm{~K}_{3} \mathrm{Fe}(\mathrm{CN})_{6}+6 \mathrm{H}_{2} \mathrm{O}+{ }_{9} \mathrm{KOH}=\mathrm{Fe}(\mathrm{OH})_{3}+6 \mathrm{NH}_{3}+6 \mathrm{CO}_{2}+ \\
& \text { I } 2 \mathrm{~K}_{4} \mathrm{Fe}(\mathrm{CN})_{6} \text {. }
\end{aligned}
$$

In our first experiments we tried to effect the oxidation without the use of a diaphragm. This was attempted both with and without a stirrer, also with the electrodes in various positions and shapes; but in all of our attempts without a diaphragm the highest yield obtained was about $50 \%$.

In all of our following experiments a diaphragm was used. The apparatus used in the next four experiments consisted of a beaker II $\mathrm{cm}$ in diameter and $2 \mathrm{I} \mathrm{cm}$ high with a capacity of about $2000 \mathrm{cc}$. The cathode chamber consisted of a porous clay cup, inside of which was placed a cylindrical iron wire gauze cathode. The anode was a 20-mesh copper wire gauze $8 \mathrm{~cm}$ by $8 \mathrm{~cm}$, and was held in a horizontal position about 2 inches from the bottom of the beaker. Just above the anode there was a glass stirrer which was rotated by a small electric motor. An ammeter was used to indicate the current. Although this would introduce an error due to the variation in current, this error was small as the variation was slight and the ammeter was read quite frequently.

\section{TABLE III}

\section{Experiment I}

To determine the amount of $\mathrm{KOH}$ formed. ${ }_{3} \mathrm{H}_{2} \mathrm{O}$.

Anode solution- $\mathrm{r}_{4} 00 \mathrm{cc}$ of saturated solution of $\mathrm{K}_{4} \mathrm{Fe}(\mathrm{CN})_{6}$ ${ }_{3} \mathrm{H}_{2} \mathrm{O}$.

Cathode solution- $75 \mathrm{cc}$ of saturated solution of $\mathrm{K}_{4} \mathrm{Fe}(\mathrm{CN})_{6 .-}$

Current-r.05 amperes (0.90 ampere per sq. dcm.).

Bath tension- 2.5 volts.

\begin{tabular}{c|c|c|c|c|c}
\hline \hline $\begin{array}{c}\text { Time after } \\
\text { starting } \\
\text { Hours }\end{array}$ & $\begin{array}{c}\text { Total KOH } \\
\text { formed } \\
\text { Grams }\end{array}$ & $\begin{array}{c}\text { KOH in } \\
\text { anode } \\
\text { chamber } \\
\text { Grams }\end{array}$ & $\begin{array}{c}\text { Percent } \\
\text { of total } \\
\text { in anode } \\
\text { chamber }\end{array}$ & $\begin{array}{c}\text { KOH in } \\
\text { cathode } \\
\text { chamber } \\
\text { Grams }\end{array}$ & $\begin{array}{c}\text { Percent } \\
\text { of total } \\
\text { in cathode } \\
\text { chamber }\end{array}$ \\
\hline 6 & I4.9 I & 6.43 & 43.2 & 8.48 & 56.8 \\
II & 24.76 & I3.2I & 53.4 & I I.54 & 46.6 \\
I6 & 35.38 & 20.08 & 56.7 & I5.3I & 43.3 \\
2 I & 42. I6 & 24.09 & 57.1 & I8.07 & 42.9
\end{tabular}


These results compare favorably with those of Grube. Thus he secured from 39 to $4 \mathrm{r}$ where we have $42.9 \%$ of total $\mathrm{KOH}$ in cathode chamber, and from $6 \mathrm{I}$ to 59 where we have $57.1 \%$ of total in anode chamber. To account for the potassium hydroxide in the anode chamber Grube gives the equation

$$
{ }_{2} \mathrm{~K}_{4} \mathrm{Fe}(\mathrm{CN})_{6}+\mathrm{O}+\mathrm{H}_{2} \mathrm{O}={ }_{2} \mathrm{~K}_{3} \mathrm{Fe}(\mathrm{CN})_{6}+{ }_{2} \mathrm{KOH} \text {. }
$$

The objecc of the next three experiments was to determine the effect of potassium hydroxide on current efficiency. The apparatus used was the same as in Experiment No. I. The current used in Experiments 2, 3 and 4 was I.25, I.I5 and I.IO amperes, respectively.

TABLE IV

Experiments 2, 3 and 4

\begin{tabular}{|c|c|c|c|c|c|c|c|}
\hline \multirow{2}{*}{ No. } & \multirow{2}{*}{$\begin{array}{l}\mathrm{K}_{4} \mathrm{Fe}(\mathrm{CN})_{6.3} \mathrm{H}_{2} \mathrm{O} \\
\mathrm{Gm} \text { per liter }\end{array}$} & \multirow{2}{*}{$\begin{array}{l}\text { Grams KOH } \\
\text { added to } \\
\text { anode } \\
\text { chamber }\end{array}$} & \multirow{2}{*}{$\begin{array}{c}\text { Amperes } \\
\text { per sq. } \\
\text { dcm. }\end{array}$} & \multicolumn{2}{|c|}{ Voltage } & \multirow{2}{*}{$\begin{array}{c}\text { Percent } \\
\text { oxidized } \\
\text { when } O \\
\text { appeared }\end{array}$} & \multirow{2}{*}{$\begin{array}{l}\text { Current } \\
\text { effi- } \\
\text { ciency }\end{array}$} \\
\hline & & & & Start & End & & \\
\hline 2 & 234.47 & 20 & 0.99 & $2 \cdot 5$ & 一 & 96.8 & 99.5 \\
\hline 3 & 286.84 & 40 & $0.9 \mathrm{I}$ & $2 . I$ & 2.0 & 98.8 & 99.0 \\
\hline 4 & 2.76 .66 & 60 & 0.86 & 2.0 & 2.0 & 98.0 & IOO. 0 \\
\hline
\end{tabular}

The current efficiency was calculated up to the time when bubbles of oxygen began to appear. This was $15,20.33$ and 20.33 hours for Experiments 2, 3 and 4, respectively.

The results show that potassium hydroxide does not decrease the current efficiency but rather increases it slightly. Also the potassium hydroxide decreases the voltage required which is a distinct gain.

The apparatus used in the following six experiments was like the one used in the preceding four, except that a rectangular glass battery jar $7^{1 / 2} \mathrm{~cm}$ by $\mathrm{I} 2 \mathrm{~cm}$ by $\mathrm{I} 7^{1 / 2} \mathrm{~cm}$ high was used instead of the tall beaker.

\section{Experiment 5}

The object of this experiment was to titrate with both potassium permanganate and sodium thiosulfate and to see whether or not all of the potassium ferrocyanide that is decomposed is converted into potassium ferricyanide. 
The electrolyte in the anode chamber consisted of rooo cc of a solution of potassium ferrocyanide containing 192.46 grams of $\mathrm{K}_{4} \mathrm{Fe}(\mathrm{CN})_{6} \cdot \mathrm{H}_{2} \mathrm{O}$ per liter. To this 30 grams of potassium hydroxide were added. The cathode chamber contained I ro cc of a $5 \%$ solution of potassium hydroxide. The anode was a $7^{1 / 2}$ by $1 \mathrm{I}^{1 / 2} \mathrm{~cm}$ copper wire gauze. The bath tension was 2.0 volts both at the start and at the end. The current varied from 0.92 to 0.95 ampere, the slight variations being noted.

Bubbles of oxygen began to appear at the end of $12.9^{2}$ hours. At this time titrations with potassium permanganate and sodium thiosulfate gave the following:

$\mathrm{KMnO}_{4}-2.78$ grams $\mathrm{K}_{4} \mathrm{Fe}(\mathrm{CN})_{6.3} \mathrm{H}_{2} \mathrm{O}$ per liter. I 47.85 grams $\mathrm{K}_{3} \mathrm{Fe}(\mathrm{CN})_{6}$ per liter (by difference). Current efficiency $99.6 \%$.

$\mathrm{Na}_{2} \mathrm{~S}_{2} \mathrm{O}_{3}-\mathrm{I}_{43} . \mathrm{I} 9$ grams $\mathrm{K}_{3} \mathrm{Fe}(\mathrm{CN})_{6}$ per liter. Current efficiency $96.5 \%$.

This goes to show that a part of the potassium ferrocyanide which is decomposed is not converted into potassium ferricyanide. This fact leads us to believe that the efficiencies in Experiments 2, 3 and 4 should be decreased by about 3\%, as the permanganate method was used. In all the following experiments the thiosulfate method was used.

The permanganate determination was made in the following manner: 5 or ro cc portions were pipetted out, diluted

- with water, acidified with dilute sulfuric acid and then titrated with decinormal potassium permanganate. The difference in the permanganate titrations, before and after a run, was taken to indicate the amount of ferrocyanide that had been oxidized to ferricyanide.

The sodium thiosulfate determination is carried out thus: To $5 \mathrm{cc}$ of the bath add about $20 \mathrm{cc}$ of water, potassium iodide solution $^{1}$ in excess (the iodine is liberated by the ferricyanide which is converted to ferrocyanide) and then about Io cc of concentrated $\mathrm{HCl}$. Shake well, add an excess of zinc sulfate

${ }^{1}$ Io grams of potassium iodide in $400 \mathrm{cc}$ water. 
solution, ${ }^{1}$ mix thoroughly and let stand for ${ }^{5}$ to 30 minutes. After standing slightly overneutralize with sodium bicarbonate and titrate with decinormal thiosulfate using starch indicator.

The permanganate method determines the ferricyanide indirectly, by assuming that all the ferrocyanide that is decomposed is converted into ferricyanide. The thiosulfate method determines the ferricyanide directly, that is, by the amount of iodine it sets free from potassium iodide.

Brochet and Petit determined ferrocyanide with permanganate, then reduced the ferricyanide and again titrated with permanganate, the difference in the titrations representing the amount of ferricyanide. Grube does not state how he determined the amount of ferricyanide.

The apparatus used in the next five experiments was the same as that used in Experiment 5. The object was to determine the effect of anode material on current efficiency.

\section{TABLE $V$}

Experiments 6, 7, 8, 9 and Io

Anode chamber-I000 cc. of potassium ferrocyanide solution.

Cathode chamber-I IO ce of $5 \%$ potassium hydroxide solution. Size of anode- $7^{1 / 2} \mathrm{~cm}$ by $1 \mathrm{I}^{1} / 2 \mathrm{~cm}$. noted.

Current varied from 0.90 to 0.95 ampere, the variations being

Temperature- $18^{\circ} \mathrm{C}$.

\begin{tabular}{|c|c|c|c|c|c|c|c|c|}
\hline \multirow{2}{*}{ No. } & \multirow{2}{*}{ Anode } & \multicolumn{2}{|c|}{ Voltage } & \multirow{2}{*}{$\begin{array}{c}\mathrm{K}_{4} \mathrm{Fe}(\mathrm{CN})_{6 \cdot 3} \mathrm{H}_{2} \mathrm{O} \\
\mathrm{Gm} \text { per liter } \\
\text { at start }\end{array}$} & \multicolumn{4}{|c|}{ Current efficiency } \\
\hline & & Start & End & & $\begin{array}{l}\text { First } \\
\text { period }\end{array}$ & $\begin{array}{l}\text { Second } \\
\text { period }\end{array}$ & $\begin{array}{l}\text { Third } \\
\text { period }\end{array}$ & $\begin{array}{c}\text { Aver- } \\
\text { age }\end{array}$ \\
\hline 6 & Copper & 2.4 & 2.1 & I $79.5 \mathrm{I}$ & 9 I. 3 & $95 \cdot 3$ & 96.3 & 94.3 \\
\hline 7 & Nickel & 2.7 & - & I $79.5 \mathrm{I}$ & $95 \cdot \mathrm{I}$ & $96 . I$ & $97 \cdot 7$ & 96.3 \\
\hline 8 & Platinum & 2.9 & 2.5 & I 82.28 & 94.6 & 94.9 & 96.6 & 95.4 \\
\hline 9 & Graphite & 3.0 & - & I 77.66 & 92.7 & $95 \cdot 9$ & 99.7 & 96.1 \\
\hline IO & $\left\{\begin{array}{l}\mathrm{Pb} \text { covered } \\
\text { with } \mathrm{PbO}_{2}\end{array}\right.$ & - & 2.3 & I 66.55 & $95 \cdot 5$ & 96.0 & 93.0 & 94.9 \\
\hline
\end{tabular}

The anodes in Nos. 6 and 7 were wire gauzes while those in Nos. 8, 9 and ro were perforated plates.

\footnotetext{
${ }^{1} 40$ grams of crystallized zinc sulfate in $400 \mathrm{cc}$ of water.
} 
The electrolysis was divided into periods as follows:

First period-from start to end of two hours.

Second period-from end 2 hours to end $3^{1 / 2}$ hours.

Third period-from end $3^{1 / 2}$ hours to end 5 hours.

These results are quite interesting. Thus with the exception of the lead peroxide anode the efficiency in each case is the highest in the third period. This is especially true of the graphite anode, the efficiency being $7 \%$ higher in the third period than in the first period. Also graphite is $2 \%$ higher in the third period than the second highest which is nickel. The efficiency of the graphite anode is almost theoretical in the third period, being $99.7 \%$.

These results seem to be at variance with those secured by Brochet and Petit, who give graphite a current efficiency of but $33.2 \%$. However, they used a larger current density and their results are for 60 minutes and it will be noted that for the first two hours our efficiency was but $92.7 \%$. It is not unusual for the efficiency of a graphite electrode to increase after being used. Thus in making sodium hypochlorite by electrolysis, if a graphite electrode is used, the efficiency is low at first but the efficiency increases with use, probably until the graphite is saturated with chlorine, when the efficiency is quite high. For nickel, lead, iron and platinum similarly low efficiencies are given by Brochet and Petit.

On the other hand Hayek says that roo\% efficiency can be obtained. Likewise Grube claims that he secured 100\% efficiency with nickel, platinum, copper, iron and lead peroxide anodes up to the time when bubbles of oxygen began to appear on the anode; however, he does not state how he determined the amount of ferricyanide formed. We never secured roo\% efficiency, the nearest being with the graphite electrode in the third period which gave $99.7 \%$ efficiency.

In the next experiment the apparatus used was the same as that used in Experiment I. The anode solution was kept saturated with ferrocyanide by the continued addition of this salt during electrolysis. The potassium ferricyanide separated out in crystals along with a little insoluble matter. 
Grube states that the ferricyanide separated out on the anode, increasing the voltage and decreasing the current efficiency. We had no trouble with this latter point. The voltage was rather constant at about 2.6. The stirret was just above the anode and continually forced the electrolyte through the gauze anode, so that the potassium ferricyanide separated out in the space below the anode instead of on the gauze.

\section{Summary of Results}

I. We were unable to secure high current efficiencies in the electrolytic oxidation of potassium ferrocyanide to potassium ferricyanide without the use of a diaphragm.

2. By leaving a space below the anode and forcing the electrolyte through it, the ferricyanide can be made to crystallize out in the space below instead of on the anode which would cause voltage losses.

3. Potassium hydroxide is found in both chambers after electrolysis.

4. Potassium hydroxide does not decrease current efficiency but rather increases it slightly and decreases the voltage.

5. All the ferrocyanide that is decomposed is not converted to ferricyanide.

6. Different current efficiencies are obtained with different electrode material and is usually greatest after the electrode has been used for about four hours. The highest current efficiency in the electrolytic oxidation of potassium ferrocyanide to potassium ferricyanide is obtained with Acheson Graphite anodes.

Laboratory of Physical Chemistry.

Indiana University

Bloomington 